US Army Corps of Engineers ${ }_{\circledast}$

Engineer Research and

Development Center

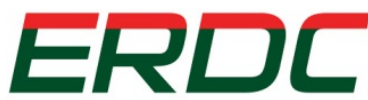

INNOVATIVE SOLUTIONS for a safer, better world

Installation Technology Transition Program

\title{
Facility Data Exchange Pilot Demonstration for the Army General Fund Enterprise Business System (GFEBS)
}

Beth A. Brucker, Mariangelica Carrasquillo-Mangual,

September 2018

Andy C. Temeyer, Jillian M. Martin, and Carl S. Mudd

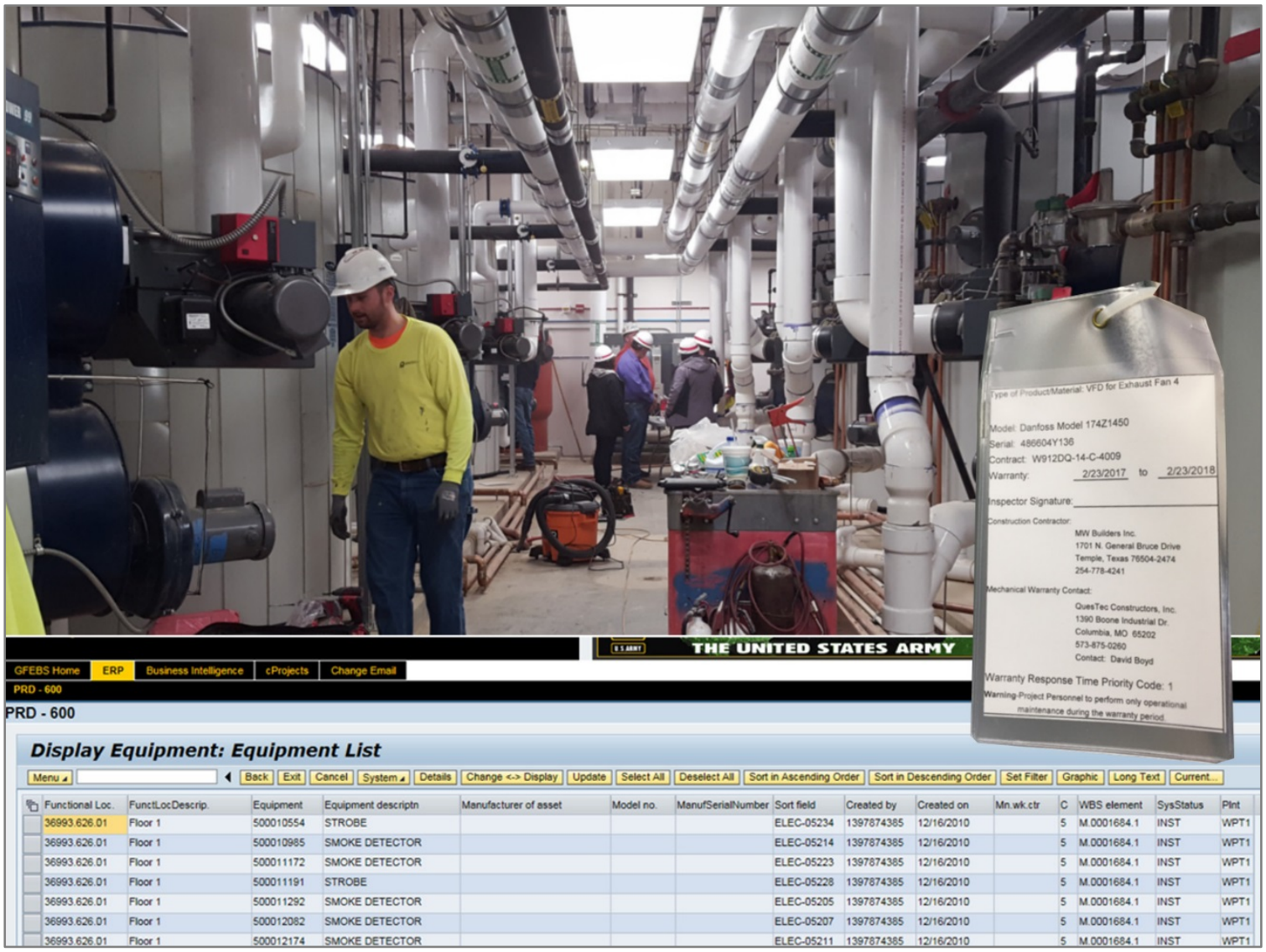


The U.S. Army Engineer Research and Development Center (ERDC) solves the nation's toughest engineering and environmental challenges. ERDC develops innovative solutions in civil and military engineering, geospatial sciences, water resources, and environmental sciences for the Army, the Department of Defense, civilian agencies, and our nation's public good. Find out more at www.erdc.usace.army.mil.

To search for other technical reports published by ERDC, visit the ERDC online library at http://acwc.sdp.sirsi.net/client/default. 


\section{Facility Data Exchange Pilot Demonstration for the Army General Fund Enterprise Business System (GFEBS)}

Beth A. Brucker and Mariangelica Carrasquillo-Mangual

Construction Engineering Research Laboratory

U.S. Army Engineer Research and Development Center

2902 Newmark Drive

Champaign, IL 61822

Andrew C. Temeyer

Omaha District

U.S. Army Corps of Engineers

1616 Capitol Avenue

Omaha, NE 68102

Jillian M. Martin

New York District, West Point Area Office

U.S. Army Corps of Engineers

667A Ruger Road

West Point, NY 12553

Carl S. Mudd

Louisville District

U.S. Army Corps of Engineers

600 Dr. Martin Luther King Place

Louisville, KY 40202-2265

Final report

Approved for public release; distribution is unlimited.

Prepared for Office of the Assistant Chief of Staff for Installation Management (OACSIM)

Arlington, VA 22202

Under Project P2 457492; Customer Order 10930002, "Facility Data Exchange Pilot" 


\section{Abstract}

The USACE/Industry BIM Consortium has been developing a specification and standardized delivery process for collecting and exchanging facility data required by the Department of Defense and the Army for downstream applications. This effort produced a new Unified Facilities Guide Specification, UFGS 0178 24.00 10 (Facility Data Requirements), which defines a prioritized set of assets and data attributes. A projectdevelopment team performed a pilot study to validate that these assets and attributes meet the Army's needs for populating their Operations and Maintenance data systems.

The focus of the pilot study was to verify that asset data collected during facility construction at three Army installations could effectively be imported to the Army General Fund Enterprise Business System (GFEBS). With the help of GFEBS experts from Installation Management Command, the project team developed a Facility Data Workbook (FDW), a spreadsheet application that facilitates the collection of facility data and translates the data into the GFEBS equipment input format. An FDW was developed for each selected facility at the pilot sites and the GFEBS input process at each installation was evaluated. Recommended changes to the specification have been drafted and will be evaluated for inclusion in an update to the guide specification.

DISCLAIMER: The contents of this report are not to be used for advertising, publication, or promotional purposes. Citation of trade names does not constitute an official endorsement or approval of the use of such commercial products. All product names and trademarks cited are the property of their respective owners. The findings of this report are not to be construed as an official Department of the Army position unless so designated by other authorized documents. 


\section{Contents}

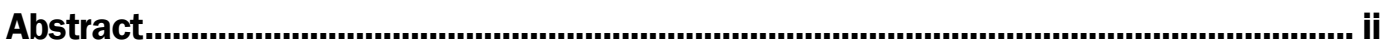

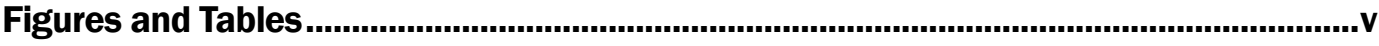

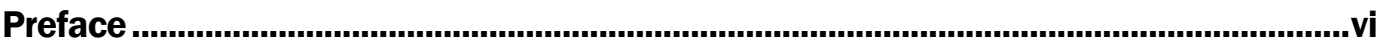

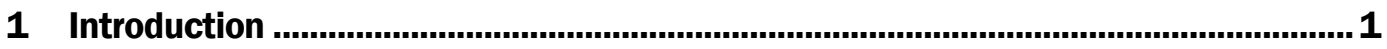

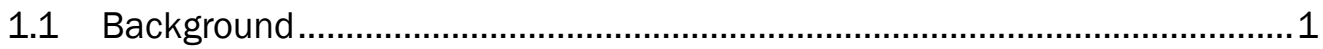

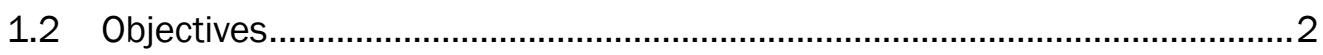

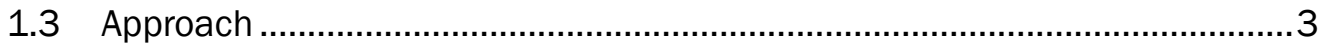

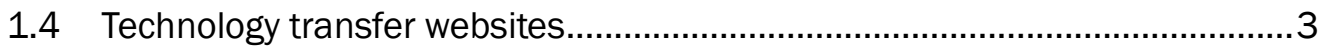

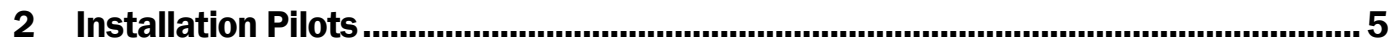

2.1 Fort Leonard Wood ......................................................................................

2.1.1 Facility data overview................................................................................ 5

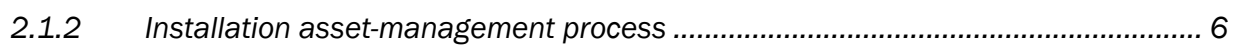

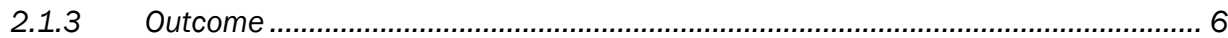

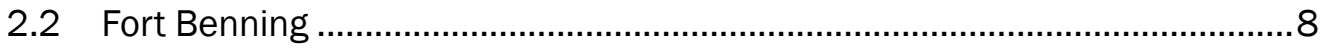

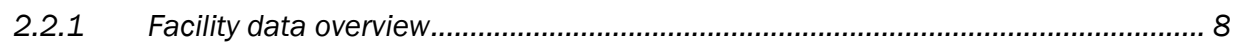

2.2.2 Installation asset-management process ........................................................ 8

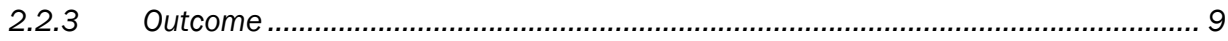

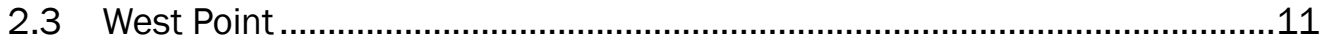

2.3.1 Facility data overview........................................................................................ 11

2.3.2 Installation asset-management process ......................................................... 11

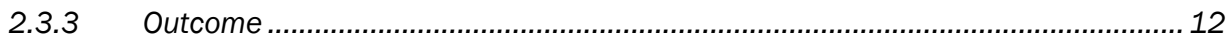

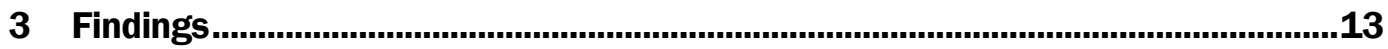

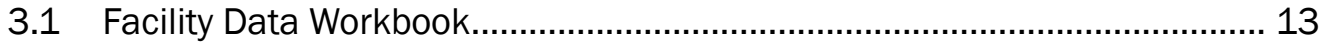

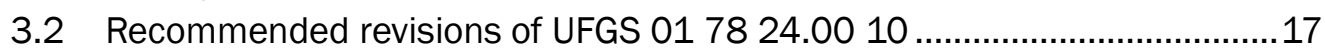

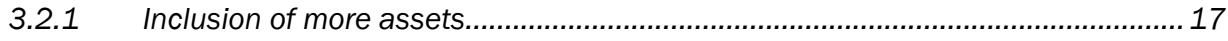

3.2.2 Statement of intent for FDW required assets.................................................. 18

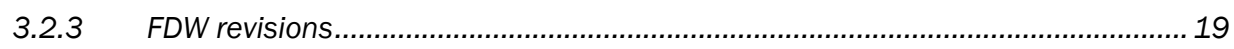

3.3 Data exchange format comparison ........................................................19

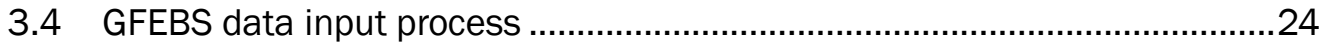

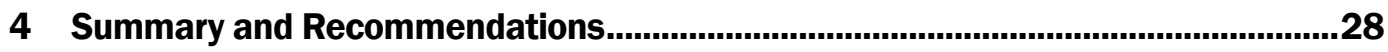

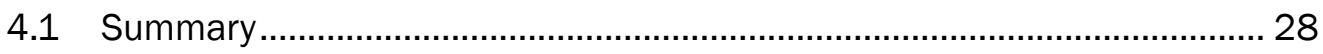

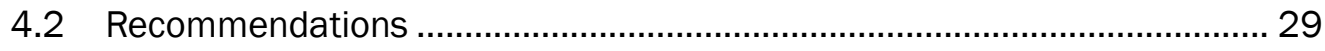

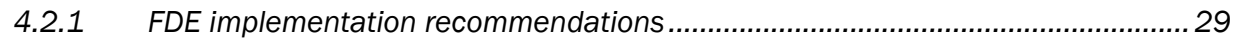

4.2.2 Related recommendations for USACE .................................................................. 29

4.2.3 Related recommendations for ASCIM and IMCOM .............................................. 30

References. 


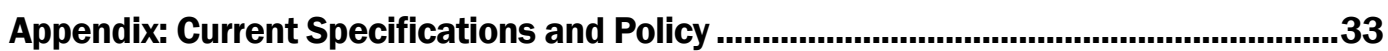

Report Documentation Page 


\section{Figures and Tables}

\section{Figures}

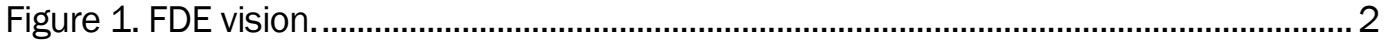

Figure 2. Warranty tag example................................................................................. 7

Figure 3. Facility Data Life-Cycle Business Process. ...........................................................15

\section{Tables}

Table 1. Cross-format data points (continued to next page)..................................................20

Table 2. Format-specific data points (continued to next page). ..........................................22

Table 3. GFEBS data input process (continued to next page). ............................................24 


\section{Preface}

This study was conducted for the Office of the Assistant Chief of Staff for Installation Management (OACSIM) under the Installation Technology Transition Program (ITTP); Project P2 457492; Customer Order 10930002, "Facility Data Exchange Pilot." The ITTP Program Manager was Natalie R. Myers, CEERD-CNN, and the Technical Monitor was Wernher Heyres, DAIM-ODF.

The work was performed by the Engineering Processes Branch of the Facilities Division (CEERD-CFN), U.S. Army Engineer Research and Development Center, Construction Engineering Research Laboratory (ERDCCERL). Charles G. Schroeder was Chief, CEERD-CFN; and Donald K. Hicks was Chief, CEERD-CF. The Deputy Director of ERDC-CERL was Dr. Kirankumar Topudurti and the Director was Dr. Lance D. Hansen.

The following members of the USACE/Industry BIM Consortium are gratefully acknowledged for their essential contributions to this work:

- Brandon Tobias, Headquarters, U.S. Army Corps of Engineers (USACE)

- Van Woods, Seattle District, USACE

- Ralph Kreider and McDonough Bolyard Peck (MBP)

- Rachel Riopel and Connor Christian, HDR, Inc.

- Carrie Dossick, University of Washington

- Birgitta Foster, VDCO Tech

The following installation support personnel are also gratefully acknowledged for providing facility access, facility data, and GFEBS guidance:

- Mark French, Fort Leonard Wood Area Office, Kansas City District

- Chris Reinhardt, Savannah District, USACE

- Maria Driscoll, Headquarters, Installation Management Command

- Leigh-Ann Lelyveld, U.S. Army Garrison West Point, Directorate of Public Works

- Leslie Espino and Desiree Crimbley, contractors supporting the Fort Benning Real Property Office

- Sara Watson, Tiya Support Services LLC, Fort Benning, GA

The Commander of ERDC was COL Ivan P. Beckman and the Director was Dr. David W. Pittman. 


\section{Introduction}

\subsection{Background}

The Army has many enterprise Operations and Maintenance (O\&M) information systems that require redundant manual input of various required facility data collected during planning, design, and construction. This duplicative work unnecessarily costs Army installations considerable time and money. Improved and coordinated processes and data standards are needed to develop O\&M data-exchange methods that are practical, consistent, and accurate in order to provide a rational digital data workflow. These methods are required to expedite input and data exchange among numerous O\&M information systems.

A working group of government and industry experts called the USACE/Industry BIM Consortium* established a Facility Data Exchange (FDE) working group to address this need. This group developed a new Unified Facilities Guide Specification (UFGS 017824.00 10, Facility Data Requirements [May 2017]), including a standard process for collecting, delivering, and exchanging facility data for downstream applications. The guide specification defines a prioritized set of facility assets and attributes and specifies a structured data format essential to populating Army installation O\&M applications. The goals of the FDE working group are described in Figure 1 (see next page).

The effort reported here, executed under the proponency of the Army Office of the Assistant Chief of Staff for Installation Management (OACSIM) Installation Technology Transition Program (ITTP), includes the FDE working group's development of a tool to facilitate the population of the Army's General Fund Enterprise Business System (GFEBS) with asset data collected during facility construction. GFEBS is the Army's "web-enabled financial, asset, and accounting management system that standardizes, streamlines, and shares critical data across the active Army, the Army National Guard, and the U.S. Army Reserve" (http://www.eis.army.mil/programs/gfebs).

\footnotetext{
* The USACE (U.S. Army Corps of Engineers)/Industry BIM (Building Information Modeling) Consortium is a working group that collaborates on mutually beneficial advanced modeling requirements for projects developing the built environment.
} 
Figure 1. FDE vision.

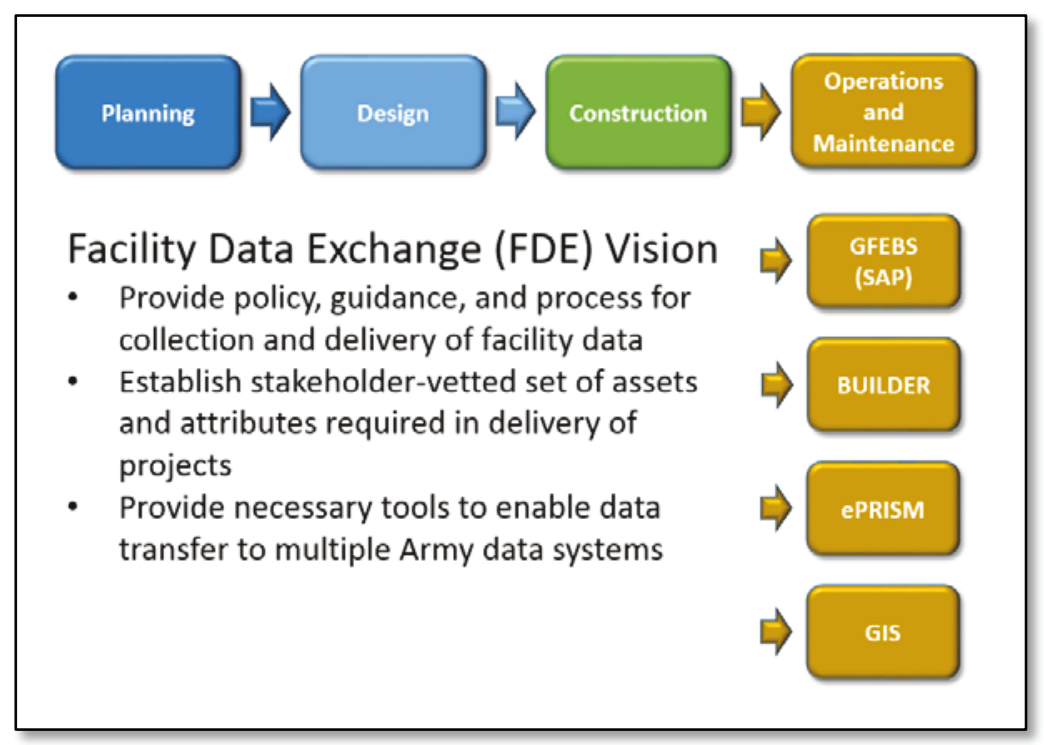

With the help of the GFEBS support team, the working group used Microsoft Excel $^{*}$ to develop a Facility Data Workbook (FDW). The FDW provides a format for collecting facility data that complies with the requirements of the initial issue of UFGS 017824.0010 and a capability to convert the data into the GFEBS equipment input format.

\subsection{Objectives}

The following objectives were set for this ITTP project:

- Develop a spreadsheet application to capture facility data required by UFGS 0178240010 and related policy, and capable of converting the facility data to the exchange format for synchronization with GFEBS

- Pilot test the spreadsheet tool on real-world facilities located at multiple Army installations

- Evaluate the results of the pilot studies, identifying successes and performance gaps

- Validate the May 2017 version of the UFGS 0178240010 FDE specification and delivery process in terms of the pilot studies, and provide recommendations for revising the guide specification to improve requirements and processes as needed

\footnotetext{
* Microsoft and Excel are registered trademarks of Microsoft Corp., Redmond, WA.
} 


\subsection{Approach}

Due to the short duration of ITTP projects, adding FDE deliverables to existing construction contracts was not feasible. Therefore, the approach was to have a FDW Project Delivery Team (PDT), consisting of USACE FDE PDT members, Kansas City District engineering and construction/project management staff, and Army Installation Directorate of Public Works (DPW) staff, populate the prototype workbook for selected facilities that were recently constructed. The FDE PDT briefed USACE Engineer District and Army Installation staff on the UFGS 017824.0010 specification, data formatting and collection process, and importation to GFEBS.

Once the GFEBS equipment input spreadsheet for each pilot facility was produced, the FDE PDT collaborated with the installation DPW staff, with the help of the Installation Management Command (IMCOM) GFEBS team, to test the GFEBS input for accuracy, reliability, and completeness. The PDT conducted this pilot testing at three installations to identify any differences in GFEBS input and usability between the facilities. At the completion of the GFEBS testing, an FDW was developed for each facility. The FDW contains Excel spreadsheets and a macro that can convert the FDE information into the GFEBS equipment input spreadsheet. A mapping and gap analysis to populate the information in GFEBS was conducted and documented.

Upon completion of the pilot tests at the three participating installations, recommended changes to the guide specification were drafted and are being evaluated for inclusion in an update of UFGS 017824.0010.

\subsection{Technology transfer websites}

A key deliverable provided by this project was PDT recommendations for updating the language of UFGS 78240010 . The current version of UFGS 0178240010 is available from the Whole Building Design Guide (WBDG) at http://www.wbdg.org. After completing the prescribed revision and approval process by Headquarters, USACE, the updated version will be available from the WBDG website. Other technology transfer documents include the following: 
- The FDW template, examples, and process guidance can be found on the USACE CAD/BIM ${ }^{*}$ Technology Center website at https://cadbimcenter.erdc.dren.mil.

- Once developed, a USACE Engineering and Construction Bulletin (ECB) about Facility Data Exchange will be available at http://www.wbdg.org/ccb/browse_cat.php?c=268.

- Any affected higher policy guidance (e.g., Engineer Regulations) can be found at http://www.publications.usace.army.mil/.

* CAD: Computer Aided Design. BIM: Building Information Modeling. 


\section{Installation Pilots}

\subsection{Fort Leonard Wood}

\subsubsection{Facility data overview}

The pilot test facilities at U.S. Army Garrison (USAG) Fort Leonard Wood* were part of the Advanced Individual Trainees (AIT) Complex II. Identification attributes of the three selected facilities are shown below:

- Battalion Headquarters (BNHQ)

○ RPUID ${ }^{\dagger}: 1279765$

○ Installation Code:29995

○ Building Number: 1790

○ Functional Location: 29995.1790

○ BOD $^{\ddagger}: 1$ Dec 2016

- Barracks/Company Operations Facility (BCOF)

○ RPUID: 1294197

○ Installation Code: 29995

○ Building Number: 1791

○ Functional Location: 29995.1791

○ BOD: 23 Feb 2017

- Dining Facility (DFAC)

○ RPUID: 1293863

○ Installation Code: 29995

- Building Number: 1792

○ Functional Location: 29995.1792

- BOD: 6 Jan 2017

The PDT for the Fort Leonard Wood pilot study consisted of ERDC-CERL, Omaha District, and Kansas City District personnel. Before the site visit, the PDT was provided contract award documents for each facility. When these facilities were chosen for the project, their completion date was scheduled for January-February 2017. There was a delay in construction and Fort Leonard Wood was still awaiting final as-built submittals for the

\footnotetext{
* In this report the authors use the designation "Fort Leonard Wood" for brevity to encompass all references to "USAG Fort Leonard Wood.

† RPUID: Real Property Unique Identifier.

‡ BOD: Beneficial Occupancy Date.
} 
BCOF from the contractor during the PDT site visit. A baseline FDW was developed before the site visit using the contract-award documents, not the as-built documents.

During the site visit the PDT was able to collect the Resident Management System (RMS) installed equipment list, warranty management plans, DD 1354 forms, ${ }^{*}$ O\&M manuals for BNHQ and DFAC, and conduct onsite tag validation of spaces and installed equipment. Assuming the FDE process were already validated and implemented, this process would not be necessary in the normal course of military construction (MILCON) or sustainment, restoration, modernization (SRM) contracts. The FDE specification would have been included in the contract, and the contractors providing the FDW would have direct access to the installed equipment as well as complete as-built documentation.

\subsubsection{Installation asset-management process}

The PDT was not able to assess the Fort Leonard Wood asset-management process during the site visit. The meeting scheduled with the Fort Leonard Wood GFEBS staff was cancelled due to their workload demands. Followup communications with Fort Leonard Wood DPW staff outlined their GFEBS use and process as follows:

- The DPW Planning Division, Real Property Section, inputs general building information from DD 1354, but not equipment information.

- No work order or preventive/equipment maintenance activity is processed through GFEBS at this time.

- The base maintenance contractor uses $\mathrm{Maximo}^{\dagger}$ or a similar application instead of GFEBS.

\subsubsection{Outcome}

A thorough site validation was performed for the Battalion HQ and DFAC facilities. The site verification process showed that $80 \%-90 \%$ of the available information provided reflected actual conditions. A less-detailed site validation was conducted for the BCOF building due to its size, but the in-

\footnotetext{
* DD Form 1354, Transfer and Acceptance of DoD Real Property.

† Maximo asset management systems, IMB Corp., Armonk, New York.
} 
formation that was verified followed patterns observed in the other two facilities. With additional data collected through onsite validation, the PDT was able to populate full FDWs for the DFAC and BNHQ. Due to the size of the BCOF, only a partial FDW was populated.

Two important observations were made during the site visit:

- The FDW room designation should exactly match the nomenclature on the building signage. During the site validation, room numbering appeared to be fairly consistent with the drawings.

- The site validation demonstrated the importance and value of enforcing and verifying the installation of warranty tags (Figure 2) as specified in contract documents (see UFGS 0178 oo, Section 1.7.5).

Discrepancies in the process for tagging warranty equipment were noted among the three facilities. It appeared to be assumed that tags are being installed as specified, but one facility was missing all tags.

Figure 2. Warranty tag example.

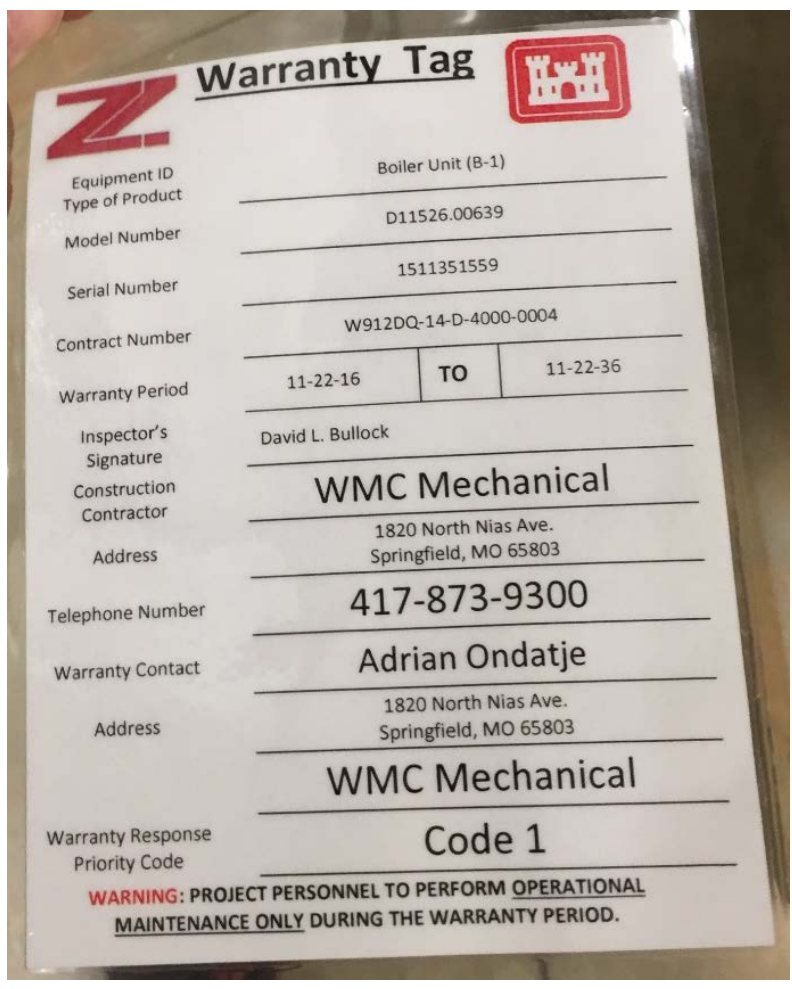




\subsection{Fort Benning}

\subsubsection{Facility data overview}

The pilot project at Fort Benning* was a Training Barracks Upgrade (Phase 2), with the following identification attributes:

- RPUID: 280943

- Installation Code: 13025

- Building Number: 3240

- Functional Location: 13025.3240

- BOD: 7 July 2016

The PDT for this facility consisted of ERDC-CERL, Louisville District, and Savannah District personnel. Before the site visit, the PDT was provided as-built drawings, specifications, and four spreadsheets supplied by the contractor containing property-replacement costs, plumbing, mechanical, fire, and alarm data. A baseline FDW was developed before the site visit using the supplied documents. Unclear or missing information was flagged while creating the baseline FDW, to be resolved or supplied during the site visit. Unclear items included discrepancies in information on the drawings, schedules, vague changes to as-built documents, or conflicts between information in the drawings and other documentation related to the same asset.

\subsubsection{Installation asset-management process}

With the support and coordination by the Savannah District Installation Support Manger, the PDT was able to meet with everyone involved in the Fort Benning asset-management process. Representatives from the DPW real property office, master planning, maintenance staff, and the contracted maintenance service provider were very helpful and engaged in the project. The PDT made several important observations during the threeday visit, as described below.

Fort Benning has a maintenance service contract with Tiya Support Services $^{\dagger}$ for all maintenance activities, including preventive maintenance

\footnotetext{
* In this report the authors have eliminated the designation "USAG" from the installation name for purposes of brevity.

† Tiya Support Services, Fort Benning, GA.
} 
plans for installed equipment. Tiya uses Maximo for work-order management and tracking of payroll and other financial activities. Tiya's level of access/role assignments in GFEBS allows the contractor to perform bulk upload of functional location and equipment information, but they do not use GFEBS for equipment tracking or maintenance activities.

The first record of information about the facility is received by Real Property personnel in a draft DD 1354 form shortly after award. It is this department's responsibility to create a record in GFEBS for the facility based on the received information. Once this is completed, GFEBS auto generates a Real Property Unique Identifier (RPUID), which is unique number for the facility that is carried through the asset's service life.

Real Property personnel create a folder for each facility. This folder contains paper copies of all DD 1354 forms, copies of warranties, and paper copies of the spreadsheet files submitted during closeout. Most of the information in these folders has not been input to GFEBS or passed to the maintenance provider.

Real Property personnel at Fort Benning seemed to be unaware of the GFEBS system capability to hold equipment-related information. Furthermore, those personnel did not appear to have sufficient levels of access/role assignments to perform functional location or equipment uploads. An attempt to upload a functional location spreadsheet failed due to missing role assignment for one staff member in Real Property.

\subsubsection{Outcome}

The PDT conducted a face-to-face meeting during the first day of the site visit. Representatives from the DPW, USACE field office engineers, and the installation maintenance contractor, Tiya, attended. The attendees were briefed about the project and it objectives. Special effort was made to solicit feedback on the initial list of required assets in order to assess whether the information was considered relevant by responsible personnel.

The kickoff meeting raised many maintenance-related issues, mostly the lack of preventive maintenance activity. Based on the discussion, the maintenance program appears to be reactive and corrective, but not preventive. Another issue identified was the lack of heating, ventilation, and air-conditioning (HVAC) system information provided to facility operators 
during the handover process. The PDT advocated that the early involvement of maintenance staff before facility turnover would be highly beneficial.

The PDT performed a site verification of installed equipment in the pilot facility. This validation focused on verifying specific items identified by the PDT while developing the baseline FDW. Personnel from Tiya accompanied PDT members during the site validation. Although the approach in this location was less thorough than at Fort Leonard Wood, the process showed that existing information about spaces and assets is mostly accurate. Inconsistency with specified or required warranty tags was also found during the walkthrough; some facilities had the required tags but others did not.

On the final day of the site visit, the PDT was able to test the upload of the collected information into the GFEBS system for the training barracks. Upload of the information was tested using the GFEBS upload functionality for functional location and equipment. A test file for functional location bulk upload was prepared by the PDT based on the information recorded in the FDW, and tested by Tiya personnel. It is understood, however, that this process probably will not be the maintenance provider's responsibility, but rather will be handled by personnel responsible for collecting the initial facility-related information. The file for uploading equipment information was initially created using the macro incorporated into the FDW for this purpose, and was appended with some installation-specific data obtained separately. Based on feedback from Tiya personnel who uploaded the data, the Excel macro may not be the most effective approach for populating the equipment-load spreadsheet. This load sheet requires information that the construction contractor will not be required to provide, such as the installation identification number. The load sheet will still require a certain amount of manual installation-specific change and cleanup. 


\subsection{West Point}

\subsubsection{Facility data overview}

At U.S. Army Garrison (USAG) West Point, ${ }^{*}$ the pilot project was the Thomas Hall HVAC Renovation. The basic identification information is as follows:

- RPUID: 360016

- Installation Code: 36993

- Building Number: 626

- Functional Location: 36993.626

- BOD: 15 May 2017

The PDT for the West Point pilot consisted of ERDC-CERL, New York District, and West Point DPW GFEBS staff. In order to establish an accurate baseline for comparison, it is important to highlight that the PDT member from the New York District was one of the renovation project managers (PMs) chosen for the pilot. In addition to her function as a PM on this project, this PDT member previously worked under the Business Operation \& Integration Division (BOID) at the West Point DPW and was involved in the development of a similar effort to collect equipment data from the construction contractor specifically for GFEBS input. Her work experience and particular familiarity with GFEBS and its functional location and equipment functionality provided a unique perspective to the FDE efforts.

\subsubsection{Installation asset-management process}

The process at West Point was found to be more structured due to past efforts to establish requirements for electronic collection and delivery of equipment data. The contract documents for the pilot project included the DPW's required format for delivery of installed-equipment information. Currently, this approach seems to be typical in West Point projects. This specific format is referred to as the "DPW Equipment Inventory Spreadsheet." The format was based on the format for the GFEBS equipment upload spreadsheet. West Point currently uses GFEBS for tracking

\footnotetext{
* In this report the authors have eliminated the designation "USAG" from the installation name for purposes of brevity.
} 
equipment information that was produced as part of an installation objective to enhance its preventive maintenance efforts.

\subsubsection{Outcome}

A PDT site visit was considered unnecessary for West Point data validation because, as noted above, one PDT member came to the group with direct experience at West Point and substantive involvement in the renovation project. It was found that DPW personnel at West Point appear to have more awareness of GFEBS capabilities as it relates to facility and equipment data. Those personnel also seem to have a clear understanding of the importance of effectively capturing and exchanging such information. This awareness may be a byproduct of the significant amount of in-house maintenance work performed by the installation. West Point currently uses GFEBS as their computerized maintenance management system (CMMS) tool. Before GFEBS was in place, the installation used the Integrated Facilities System (IFS) for facility management. That fact is particularly significant because migration between the two systems negatively impacted the data structure in terms of the relation of spatial and equipment information to the facility. This migration issue required additional data cleanup steps for existing facilities before renovated or updated equipment could be uploaded for this pilot project. Detailed input about this issue, including steps and recommendations for correcting it, were provided to the PDT. It was found that categorization of equipment in GFEBS directly relates to the type of work performed by the different maintenance shops at the installation.

Another key aspect of West Point is its structured process for collection and exchange of asset information. That process includes communication with the construction contractor during the pre-construction conference to establish the specific format required for delivery of the "Equipment-In Place" list that is included in Contract Specification 017823 (i.e., UFGS 01 78 23, "Operation and Maintenance Data"). In the case of this project, the DPW's Equipment Inventory Spreadsheet was used instead of the FDW. An FDW was then developed by the PDT based on the contractor-delivered equipment inventory spreadsheet. Although this approach deviated from the other two pilot studies it provided useful verification feedback related to the information and requirements for the FDW and specification. To demonstrate the differences, a comparison table including both formats and the GFEBS upload spreadsheet is included in Chapter 3. 


\section{Findings}

Research conducted before and during this pilot project found that language requiring the collection and delivery of facility and equipment data is already included in USACE and IMCOM construction contracts. This language is found in many different policy and specification documents such as Unified Facilities Guide Specifications (UFGS), Executive Orders, DoD Issuances (http://www.esd.whs.mil/DD/DoD-Issuances/), and other guidance. A summary of relevant extracts is included in the Appendix.

This pilot study confirmed to the PDT that there is a need for cohesive policy and guidance that explicitly states which data are to be delivered and, most importantly, how the data should be delivered. The absence of specific guidance has hindered the implementation of standard data-exchange formats such the Construction Operation Building information exchange (COBie). The FDE working group used the COBie exchange standard as the underlying exchange framework to develop the FDW, but added data definition and requirements within the template in order to improve exchange with GFEBS.

The equipment data currently defined in the FDE specification and the FDW is not intended to be a complete list of every piece of equipment needing maintenance at an installation. At this point its purpose is to identify a subset of equipment types and attributes to be further expanded and defined by facility owners and maintainers. Pilot study findings and observations are discussed below.

\subsection{Facility Data Workbook}

The FDW was developed to structure and standardize required information to facilitate data submittal and exchange. Through this effort, the basic process of populating the FDW was developed. The process followed by the PDT was not identical to data collection during construction, but was similar to that of a separate contract to provide the FDW under its own scope of work. It was found by the PDT that an average building takes approximately 8-24 hours of labor for FDW population and 8-16 hours for field verification and refinement. Variables that affect the population of the FDW include building size and complexity, building systems, completeness of design documents, O\&M documentation, and other supporting documentation. 
The pilot studies also reconfirmed that the information collected in the FDW is currently required by standard specification language that is already included in most USACE and IMCOM contracts.

The organizational 'stovepipes' within both Fort Leonard Wood and Fort Benning made it difficult to identify appropriate installation-level proponents for this type of deliverable. At West Point, however, this was not a problem, possibly due to installation size and established data management processes (see section 2.3.2)

The business process model, illustrated in Figure 3, demonstrates the flow of facility data and information through the project life-cycle. Project phases are represented by vertical "swim lanes," and process participants are represented by horizontal "pools." The proposed flow of the FDW is highlighted in green and integration of the information in GFEBS is highlighted in yellow. Within the GFEBS integration process, black text indicates the activities currently implemented and blue text shows observed gaps or inconsistencies in the current process. 
Figure 3. Facility Data Life-Cycle Business Process.

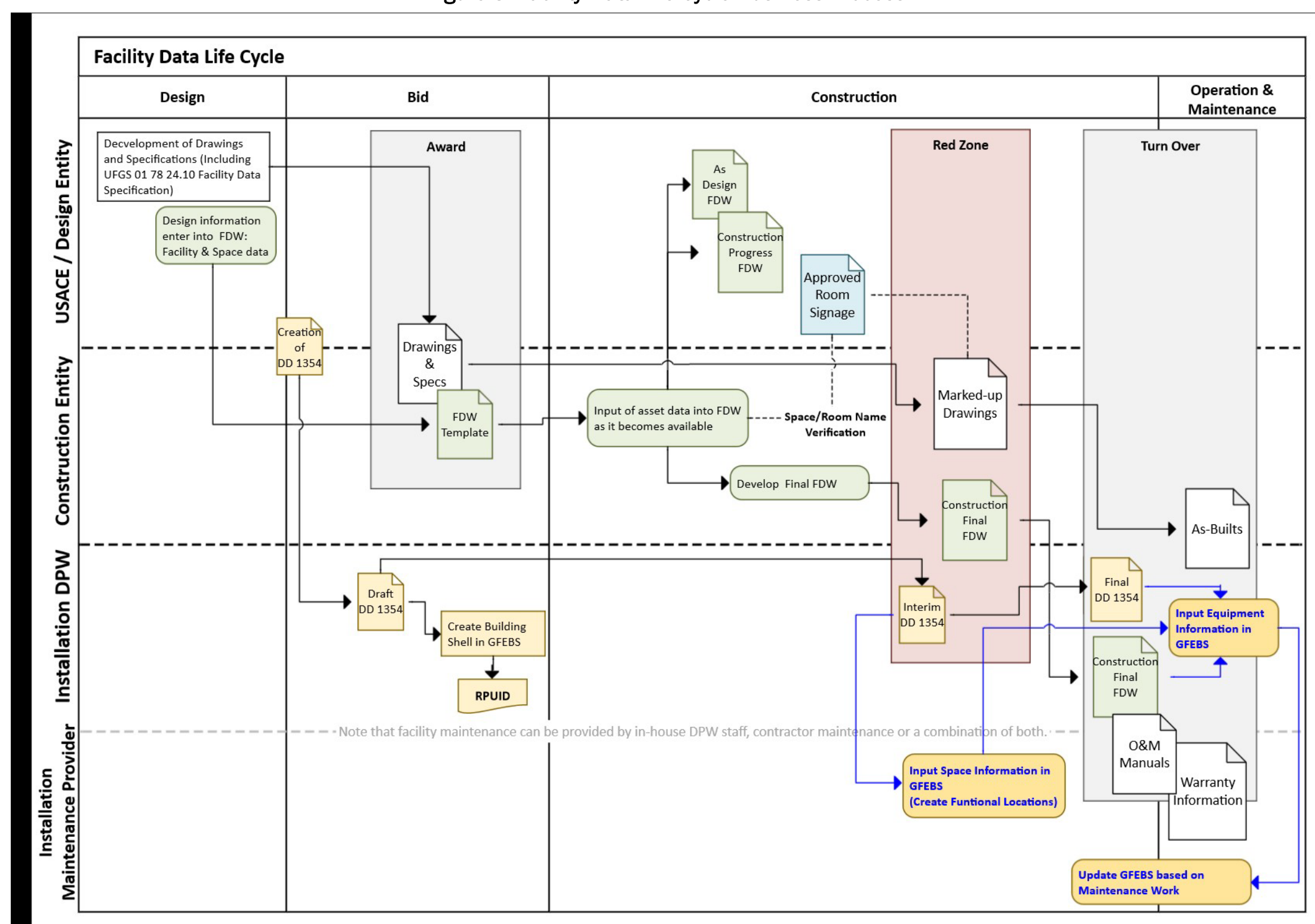


The PDT found that the FDW-required assets list could be improved upon. Mechanical and electrical systems are complex, often unique to each building, and can be defined and engineered in a variety of ways. Current terminology and lack of definitions on FDW asset list led to inconsistent interpretations of requirements by users in the project. Simplifying the terminology and listing examples, abbreviations, and synonyms may help to minimize potential for conflict. Simplification and examples could answer questions frequently raised by the PDT, such as the following:

- What is included in the Decentralized Unitary HVAC Equipment category?

- Why do we call for low- and medium-voltage panels and switchgear inside the plant, but high- and medium-voltage outside the plant-is that distinction intentional?

A few significant system components found during the pilot studies had not been included in the FDW-required asset list. The PDT identified several that should be considered for addition.

- Variable-frequency drives and devices

- Domestic water and HVAC tanks

- Surge-protection devices

- Telecom equipment

- Electronic trap primers

- Kitchen equipment

- Grease traps and oil/water separators

- Material-handling equipment (cranes, lifts, etc.)

The ease of populating the FDW is directly affected by the way design documents are developed. The PDT heavily relied on mechanical, electrical, and plumbing construction document schedules for gathering data. Neither schedules nor their content are standardized across the industry. This situation creates challenges which, when repeated over hundreds of projects, can produce inconsistencies in the compiled data set. Examples include the following:

- Differences in terminology (e.g., "backwater valve" versus "backflow preventer")

- Differences in type versus instance scheduling, which can affect asset identification nomenclature 
During the course of this project, the PDT did find a few relatively minor design documentation and closeout submittal errors or inconsistencies. Examples include annotation or labeling errors in the design documents and mislabeled space names, numbers, and equipment locations. These raised the question of whether there should there be a process or requirement to reconcile these findings in documents

The PDT also found that the spreadsheet macro developed to translate FDW data to GFEBS format may not be the most effective approach to populating the equipment-load spreadsheet. This load sheet requires information that the construction contractor will not be responsible for providing, such as the installation identification number. Additionally, the load sheet will still require manual installation-specific changes and cleanup.

\subsection{Recommended revisions of UFGS 017824.0010}

Part of the deliverable product for the PDT's task of validating UFGS 0178 24.00 10 was to recommend revisions of the guide specification. A draft specification containing these changes was provided to Headquarters, USACE by the PDT. The key recommendations are discussed below.

\subsubsection{Inclusion of more assets}

The primary recommended change was to allow the addition of assets to the project scope of work using a table built into the guide specification. Previously, the FDW "Required Assets" list was fixed. Inclusion of this table will enable the specifier to quickly add assets based on installation-specific needs. This table was added to the specification instead of the FDW because it pairs project-specific additional requirements with the projectspecific requirements of the guide specification. Building these requirements into the FDW template would mean that any project-specific assets would have to be attached as an appendix to the guide specification, and the digital file would have to be transmitted to the contractor upon award. Using the FDW this way in the workflow was determined to be inefficient.

The ITTP pilot studies made it clear that different installations will have a minimum set of baseline assets that they inventory and track. While the Required Assets list covers a core set of items, installations almost always need to add other assets based upon local requirements. This list of important peripheral assets varies among installations, so it seemed most 
prudent to add them to the core Required Assets in the guide specification. However, the PDT's recommendations pertaining to the new table included some bracketed values that may be common enough to add to the UFGS. Examples include the following::

- Fixtures, furnishings, and equipment (FF\&E)

- Kitchen equipment and fixtures

- Valves

- Tanks and vaults

- Material-handling equipment

- DDC and EMCS equipment

- All inspectable equipment

Adding this table to the UFGS allows for these recommended items, or others, to be captured without adding them to the core set of Required Assets in the FDW.

\subsubsection{Statement of intent for FDW required assets}

The PDT recommended revising the UFGS to include a statement of intent relating to the FDW required assets. The ITTP effort made it clear that regardless of efforts to identify the most common core set of facility assets, designs are inherently customizable to meet installation-specific needs. While the Required Assets list is intended to define and limit the scope of FDW assets, it also has the potential to exclude important specialty equipment needed for specific facilities. To that end, the "Assets" paragraph of the UFGS (section 2.2.2) was refined as follows:

Compile an FDW that contains the ,] maintainable and warrantable equipment (assets) associated with each facility. This includes assets in contract scope and within the project extents. See 0178 oo CLOSEOUT SUBMITTALS [and 017823 OPERATION AND MAINTENANCE DATA] for related requirements. Assets shall include but are not limited to those types described in the "Required Assets" portion of the FDW template [, those assets listed in the table below, ] and any additional assets defined in the FDPxP. FDW asset entries shall be individually itemized (instance-based). Entries indicative of multiple assets (type-based) are not allowed. 
In short, the Required Assets list should still be understood to be a baseline data set, but the statement of intent clarifies that all significant mechanical and electrical equipment should be populated in the FDW. The Required Assets list is being adjusted to more clearly define the desired groups of assets.

\subsubsection{FDW revisions}

While the PDT identified several assets and asset groups that were worth considering for addition to the FDW Required Assets list, it was ultimately decided to not add any of them. Nevertheless, the results of the work make it clear that there is a need to realistically address the issue of terminology in construction documents, which varies widely for these assets. A single standard term or definition from an individual classification system is not adequate for defining the scope of potential desired assets. Therefore, there is need to restructure the Required Assets tab of the FDW. Longform definitions and/or synonyms will be added to each asset listing to better define the intended scope. The FDE PDT intends to investigate all the different classification systems to come to a set of common definitions. Several classification systems already carry definitions for these assets, and a list of some of these will be added to the Required Assets tab.

The FDW PDT believes these changes to the FDW and guide specification will go a long way to better define the intended scope for populating the FDW. These changes build some much-needed flexibility into both the FDW and specification to enable the PDT to meet stakeholder needs for facility data.

\subsection{Data exchange format comparison}

During this work the PDT learned that New York District and West Point had implemented a structured data-management process that includes an approach similar to this FDE-to-GFEBS pilot project. During the preconstruction conference for West Point projects, the contractor is given a DPW Equipment Inventory spreadsheet formatted to collect and submit installedequipment data. Due to similarities in the objective and implementation process, the PDT took this opportunity for further testing and validation of the proposed requirements.

It is important to highlight that, although similar, the end goals of both efforts differ. The West Point DPW Equipment Inventory spreadsheet was 
designed with the sole purpose of collecting the information from contractors in the GFEBS-required format for processing bulk upload of equipment data. Therefore, West Point's format is a subset-essentially a refined version-of the GFEBS upload spreadsheet. The end goal of the FDW, however, is to provide a format capable of not only populating GFEBS but also other downstream O\&M applications used by Army and DoD installations.

Table 1 and Table 2 show the FDW PDT's comparison of the data points included in the available formats. The first table focuses on the information found across all three formats while the second table focuses on format specific data points.

Table 1. Cross-format data points (continued to next page).

\begin{tabular}{|c|c|c|c|}
\hline Data Point & $\begin{array}{l}\text { Facility Data Workbook } \\
\text { (FDW) }\end{array}$ & $\begin{array}{l}\text { West Point DPW } \\
\text { Equipment Inventory }\end{array}$ & $\begin{array}{l}\text { GFEBS } \\
\text { Equipment Upload }\end{array}$ \\
\hline \multirow[b]{2}{*}{ Equipment Identification ${ }^{1}$} & $\begin{array}{l}\text { Asset Designation } \\
\text { (Tab 3, Asset Data, Column C) }\end{array}$ & & \\
\hline & $\begin{array}{l}\text { Asset Description } \\
\text { (Tab 3. Asset Data, Column D) }\end{array}$ & $\begin{array}{l}\text { Description } \\
\text { (Column B) }\end{array}$ & $\begin{array}{l}\text { Description } \\
\text { (Column J) } \\
\text { Required Value }\end{array}$ \\
\hline \multirow[b]{3}{*}{ Equipment Location² } & $\begin{array}{l}\text { Facility Designation } \\
\text { (Tab 1. Facility Data, Column D) }\end{array}$ & $\begin{array}{l}\text { Building Number } \\
\text { (Column K) }\end{array}$ & \multirow{3}{*}{$\begin{array}{l}\text { Functional Loc. } \\
\text { (Column AN) } \\
\text { Required Value } \\
\text { Functional location is a GFEBS- } \\
\text { specific value. Used to locate each } \\
\text { space or asset in the building, it is } \\
\text { a dot-separated concatenation of } \\
\text { site, building, level, and room } \\
\text { information structured from } \\
\text { generic to specific. } \\
\text { A Room field is provided in column } \\
Z \text { but, not required. }\end{array}$} \\
\hline & $\begin{array}{l}\text { Level Designation } \\
\text { (Tab 2. Space Data, Column G) }\end{array}$ & $\begin{array}{l}\text { Floor Number } \\
\text { (Column L) }\end{array}$ & \\
\hline & $\begin{array}{l}\text { Space Designation } \\
\text { (Tab 3. Asset Data, Column E) } \\
\text { Space Designation is a list } \\
\text { populated from Space data on } \\
\text { Tab } 2 \text { which identifies the level, } \\
\text { description and classification } \\
\text { for the space. }\end{array}$ & $\begin{array}{l}\text { Room Number } \\
\text { (Column M) }\end{array}$ & \\
\hline Equipment Classification 3 & $\begin{array}{l}\text { Asset Classification } \\
\text { (Tab 3. Asset Data, Column G) }\end{array}$ & $\begin{array}{l}\text { Equipment Category } \\
\text { (Column A) }\end{array}$ & $\begin{array}{l}\text { Equipment Category } \\
\text { (Column E) } \\
\text { Required Value }\end{array}$ \\
\hline System Classification 4 & $\begin{array}{l}\text { System Designation System } \\
\text { Classification (Columns H \& I) }\end{array}$ & $\begin{array}{l}\text { Equipment Category } \\
\text { (Column A) }\end{array}$ & $\begin{array}{l}\text { Equipment Category } \\
\text { (Column E) } \\
\text { Required Value }\end{array}$ \\
\hline Equipment Manufacturer 5 & $\begin{array}{l}\text { Manufacturer } \\
\text { (Tab 3. Asset Data, Column K) }\end{array}$ & $\begin{array}{l}\text { Manufacturer } \\
\text { (Column D) }\end{array}$ & Manufacturer (Column M) \\
\hline Manufacturer Part Number & & $\begin{array}{l}\text { Manufacturer Part No. } \\
\text { (Column G) }\end{array}$ & $\begin{array}{l}\text { ManufPartNo. } \\
\text { (Column R) }\end{array}$ \\
\hline Manufacturer Model Number & $\begin{array}{l}\text { Manufacturer Model Number } \\
\text { (Tab 3. Asset Data, Column L) }\end{array}$ & $\begin{array}{l}\text { Model Number } \\
\text { (Column F) }\end{array}$ & $\begin{array}{l}\text { Model number } \\
\text { (Column 0) }\end{array}$ \\
\hline
\end{tabular}




\begin{tabular}{|c|c|c|c|}
\hline Data Point & $\begin{array}{l}\text { Facility Data Workbook } \\
\text { (FDW) }\end{array}$ & $\begin{array}{l}\text { West Point DPW } \\
\text { Equipment Inventory }\end{array}$ & $\begin{array}{l}\text { GFEBS } \\
\text { Equipment Upload }\end{array}$ \\
\hline Manufacturer Serial Number & $\begin{array}{l}\text { Serial Number } \\
\text { (Tab 3. Asset Data, Column M) }\end{array}$ & $\begin{array}{l}\text { Manufacturer Serial No. } \\
\text { (Column H) }\end{array}$ & $\begin{array}{l}\text { ManufserialNo. } \\
\text { (Column S) }\end{array}$ \\
\hline Equipment Weight & & $\begin{array}{l}\text { Weight } \\
\text { (Column I) } \\
\text { Data captured in Ibs }\end{array}$ & $\begin{array}{l}\text { Weight } \\
\text { (Column AE) }\end{array}$ \\
\hline Equipment Size & & $\begin{array}{l}\text { Size/Dimension/ Capacity } \\
\text { (Column J) } \\
\text { Unit specification required }\end{array}$ & $\begin{array}{l}\text { Size/Dimension } \\
\text { (Column AF) }\end{array}$ \\
\hline Installation Information & $\begin{array}{l}\text { Installation Date } \\
\text { (Tab 3. Asset Data, Column 0) }\end{array}$ & & $\begin{array}{l}\text { Start-up d } \\
\text { (Column AG) }\end{array}$ \\
\hline Equipment Turn Over6 & $\begin{array}{l}\text { Installation Date } \\
\text { (Tab 3. Asset Data, Column 0) }\end{array}$ & $\begin{array}{l}\text { Valid From } \\
\text { (Column C) } \\
\text { Define as date on which } \\
\text { equipment becomes } \\
\text { government property }\end{array}$ & $\begin{array}{l}\text { Valid From } \\
\text { (Column L) } \\
\text { Required Value }\end{array}$ \\
\hline Equipment Tag & $\begin{array}{l}\text { Tag Number } \\
\text { (Tab 3. Asset Data, Column J) }\end{array}$ & $\begin{array}{l}\text { Equipment Tag } \\
\text { Define as information located } \\
\text { on equipment tag (local } \\
\text { numbering system) }\end{array}$ & $\begin{array}{l}\text { Equipment } \\
\text { (Column F) }\end{array}$ \\
\hline \multirow[t]{2}{*}{ Warranty Period7 } & $\begin{array}{l}\text { Warranty Start Date } \\
\text { (Tab 3. Asset Data, Column P) }\end{array}$ & $\begin{array}{l}\text { Warranty Begin Date } \\
\text { (Column 0) }\end{array}$ & $\begin{array}{l}\text { Begin Guar } \\
\text { (Column AS) }\end{array}$ \\
\hline & $\begin{array}{l}\text { Warranty Duration } \\
\text { (Column Q) } \\
\text { Date captured in } \\
\text { (YYY/MM/DD) } \\
\text { Duration captured in (months) }\end{array}$ & $\begin{array}{l}\text { Warranty End Date } \\
\text { (Column P) } \\
\text { Data captured in } \\
(\mathrm{MM} / \mathrm{DD} / \mathrm{MY})\end{array}$ & $\begin{array}{l}\text { Warranty e } \\
\text { (Columns AS \& AT) } \\
\text { Data captured in } \\
\text { (MM/DD/YY) }\end{array}$ \\
\hline
\end{tabular}

1. FDW asset designation is a unique identifier for each piece of installed equipment. GFEBS Upload format utilizes a sequential system, record_num, in the first column as the unique identifier. The value on the FDW Asset Designation field often corresponds to the identification number on the equipment tag which is captured by the three formats being compared.

2. Due to the system-specific format for identifying location, manual manipulation will be required regardless of the currently available format utilized for data collection during construction.

3. Categorization/Classification of assets in DPW inventory and GFEBS upload formats are based on system-specific values for the type of information. Categorization/Classification of assets in the FDW is based on standard classification systems due to its design to be system-neutral.

4. Based on values and definitions, information captured in the Equipment Category field is similar to System Designation. Therefore, this System Classification row is a better fit in terms of data mapping than the Equipment Classification row.

5. Both the West Point DPW and GFEBS Upload formats capture the country in which the equipment was manufactured in columns $\mathrm{E}$ and $\mathrm{N}$ respectively. The FDW format captures the manufacturer email on column $\mathrm{N}$ of Tab 3. 
6. The GFEBS upload template format contains a separate, undefined, unrequired field label "Delivery D" in column BB. A description or definition is not provided for either of the fields. Therefore, mapping on this specific row is assumed to be correct based on available information and PDT knowledge of the process, formats, and GFEBS. As this is a required value in GFEBS, the current FDW-to-GFEBS upload template process maps the Installation Date value to the "Valid From" field, as shown above.

7. The GFEBS system is programmed to issue a warning if work is called to a piece of equipment prior to its warranty period being completed.

Table 2. Format-specific data points (continued to next page).

\begin{tabular}{|c|c|c|c|}
\hline Data Point & $\begin{array}{l}\text { Facility Data Workbook } \\
\text { (FDW) }\end{array}$ & $\begin{array}{l}\text { West Point DPW } \\
\text { Equipment Inventory }\end{array}$ & $\begin{array}{l}\text { GFEBS } \\
\text { Equipment Upload }\end{array}$ \\
\hline Replacement Information & & $\begin{array}{l}\text { Replacement } \\
\text { If Yes, describe } \\
\text { (Column Q \& R) } \\
\text { Q: Y/N data field }\end{array}$ & \\
\hline O\&M Manual Information ${ }^{1}$ & & $\begin{array}{l}\text { O\&M Manual No. } \\
\text { (Column T) } \\
\text { This field intent to capture } \\
\text { reference information to O\&M } \\
\text { manual such as title, volume, } \\
\text { and file location. }\end{array}$ & \\
\hline Warranty Priority ${ }^{2}$ & $\begin{array}{l}\text { Warranty Description } \\
\text { Warranty Priority Code } \\
\text { (Tab 3. Asset Data, Columns R } \\
\text { \& S) }\end{array}$ & & \\
\hline Additional Information ${ }^{3}$ & & $\begin{array}{l}\text { Additional Information } \\
\text { (Column U) }\end{array}$ & \\
\hline Facility and Project Information & $\begin{array}{l}\text { Project Designation } \\
\text { Project Description } \\
\text { Design Agent } \\
\text { Construction Contractor } \\
\text { Facility Description } \\
\text { (Tab 1. Facility Data, Columns C } \\
\text { - F \& G ) }\end{array}$ & & \\
\hline Classification & & $\begin{array}{l}\text { Cla (Column K) } \\
\text { Required Value } \\
\text { Classification used by the } \\
\text { system. Value seems to be } \\
\text { default to } 002 \text { for all } \\
\text { installations. }\end{array}$ & \\
\hline
\end{tabular}




\begin{tabular}{|c|c|c|c|}
\hline Data Point & $\begin{array}{l}\text { Facility Data Workbook } \\
\text { (FDW) }\end{array}$ & $\begin{array}{l}\text { West Point DPW } \\
\text { Equipment Inventory }\end{array}$ & $\begin{array}{l}\text { GFEBS } \\
\text { Equipment Upload }\end{array}$ \\
\hline Site Information & & $\begin{array}{l}\text { Plant (Column T) } \\
\text { Plant (Column W) } \\
\text { Main (Column Y) Required } \\
\text { Value } \\
\text { These values defined the } \\
\text { installations involved with } \\
\text { maintenance of the } \\
\text { Equipment. Each installation } \\
\text { is defined by a four-character } \\
\text { code. } \\
\text { Comp (Column AH) } \\
\text { Business Area (Column Al) } \\
\text { Required Value } \\
\text { These values default to ARMY } \\
\text { in all examples covered by } \\
\text { this project. }\end{array}$ & \\
\hline Space Information & $\begin{array}{l}\text { Space Description } \\
\text { Space Classification } \\
\text { Space Signage } \\
\text { Level Classification } \\
\text { (Tab 2. Space Data, Columns D } \\
\text { - F \& H ) }\end{array}$ & & \\
\hline Life Expectancy & & $\begin{array}{l}\text { Life Expectancy } \\
\text { (Column N) }\end{array}$ & \\
\hline Reference to Specification Section & $\begin{array}{l}\text { Spec Reference } \\
\text { (Tab 3. Asset Data, Columns F) }\end{array}$ & & \\
\hline
\end{tabular}

Notes for Table 2

1. This information is currently stored in a Notes \& Text field available in GFEBS for each piece of equipment. Since this is a text field, a temporary mapping solution can include this information in the warranty description field (refer to next row).

2. Although not specifically captured in the additional two formats, this information is required by the Closeout Submittals specification, USGS 017800 , section 1.7.4, as well as part of the information required for the Warranty Tag specified in section 1.7.5 of the same specification.

3. This information is currently stored in a Notes \& Text field available in GFEBS for each piece of equipment. West Point staff indicated that this text field often includes information to help technician locate equipment on sites such as Pad/Pole mounted. It was also indicated that this information gets manually uploaded into a notes field in GFEBS. As a temporary solution, this information could be captured as part of the FDW Asset Description field.

As expected, given the similarities stated at the beginning of this section, results showed that roughly $75 \%$ of the data points captured are similar across formats. Variations among the remaining $25 \%$ percent of the data points are related to system or process-specific requirements, reinforcing the need for standardization. Another common difference shown from the comparison exercise is the naming convention and level of detail required for each data type which, in this case, is driven by the end goal and assumptions established during the process of designing each format. 
The gap analysis confirmed the PDT's expectations. It is important to note that no format would provide a $100 \%$ solution for transferring information to all systems nor would it be a practical and economical goal. As stated several times throughout this report the expectation is to collect a baseline set of information that can be further modified to satisfy the installation's downstream system requirements.

\subsection{GFEBS data input process}

Table 3 outlines the major steps needed to integrate structured spatial and equipment information, such as that in the FDW, into GFEBS. This process will be required on any type of project, internal or external, that involves modification of any piece of real property installed equipment record in GFEBS. The steps and discussion included in this section fall under the Property, Plant \& Equipment (PP\&E) business process. As defined in release 1.4 of the GFEBS role description document (https://www.us.army.mil/suite/doc/30739382), PP\&E includes Real Property (RP), Plant Maintenance and Project System (PM\&PS), and Equipment and Assets (EA). Table 3 is based on GFEBS documentation and personnel interviews conducted during the pilot installation visits. During the course of the West Point pilot, it was noted that existing information in GFEBS might require cleanup due to the IFS conversion process.

Table 3. GFEBS data input process (continued to next page).

\begin{tabular}{|c|c|c|c|c|c|c|}
\hline Step & Description & $\begin{array}{l}\text { Reference } \\
\text { Documents }\end{array}$ & $\begin{array}{l}\text { Business } \\
\text { Process } \\
\text { Area }\end{array}$ & T-Code & $\begin{array}{l}\text { Applicable GFEBS } \\
\text { Permission or Role }\end{array}$ & Actions Taken \\
\hline 1 & $\begin{array}{l}\text { Create/Update } \\
\text { RP record, } \\
\text { Input/Update } \\
\text { Facility } \\
\text { Information }\end{array}$ & $\begin{array}{l}\text { Draft DD } \\
1354\end{array}$ & $\begin{array}{l}\text { Real Property } \\
\text { (RP) }\end{array}$ & $\begin{array}{l}\text { - IL05 } \\
\text { (Structure Tab) }\end{array}$ & $\begin{array}{l}\text { - RP Maintainer } \\
\text { - RP Viewer } \\
\text { - RP Inventory/Inspection } \\
\text { Processor } \\
\text { - RP Interface Processing } \\
\text { Monitor }\end{array}$ & $\begin{array}{l}\text { - RP record } \\
\text { verified/create in GFEBS } \\
\text { master data } \\
\text { - RPUID generated } \\
\text { - Record information } \\
\text { send to applicable } \\
\text { external systems }\end{array}$ \\
\hline \multicolumn{3}{|c|}{ Recommended Communication: } & \multicolumn{4}{|c|}{ RPUID from installation to construction agent. } \\
\hline 2 & $\begin{array}{l}\text { Update RP } \\
\text { record with } \\
\text { spatial (floor } \\
\text { and spaces) } \\
\text { information }\end{array}$ & $\begin{array}{l}\text { - GFEBS } \\
\text { Functional } \\
\text { Location } \\
\text { upload } \\
\text { spreadsheet } \\
\text { - Approved } \\
\text { Progress } \\
\text { FDW } \\
\text { submittal }\end{array}$ & $\begin{array}{l}\text { Real Property } \\
\text { (RP) }\end{array}$ & $\begin{array}{l}\text { - ZSPPE_DATALOAD } \\
\text { (Bulk Upload) } \\
\text { - IL05 } \\
\text { (Display Result) } \\
\text { - IL01 (Crate Fun Loc) } \\
\text { - IL02 (Edit Fun Loc) }\end{array}$ & $\begin{array}{l}\text { - Asset Data Maintainer } \\
\text { - RP Viewer } \\
\text { - Real Estate } \\
\text { Contracts } \backslash \text { Space } \\
\text { Utilization Maintainer }\end{array}$ & $\begin{array}{l}\text { Functional Location } \\
\text { records created for } \\
\text { facility spaces }\end{array}$ \\
\hline \multicolumn{3}{|c|}{ Recommended Communication: } & \multicolumn{4}{|c|}{ Communicate to department/division responsible for assets/equipment } \\
\hline
\end{tabular}




\begin{tabular}{|c|c|c|c|c|c|c|}
\hline Step & Description & $\begin{array}{l}\text { Reference } \\
\text { Documents }\end{array}$ & $\begin{array}{l}\text { Business } \\
\text { Process } \\
\text { Area }\end{array}$ & T-Code & $\begin{array}{l}\text { Applicable GFEBS } \\
\text { Permission or Role }\end{array}$ & Actions Taken \\
\hline 3 & $\begin{array}{l}\text { Input/Update } \\
\text { Equipment } \\
\text { Information }\end{array}$ & $\begin{array}{l}\text { - GFEBS } \\
\text { Equipment } \\
\text { upload } \\
\text { Spreadsheet } \\
\text { - Accepted } \\
\text { Final FDW } \\
\text { submittal }\end{array}$ & $\begin{array}{l}\text { Plant } \\
\text { Maintenance } \\
\text { (PM) } \\
\text { Equipment \& } \\
\text { Assets (EA) }\end{array}$ & $\begin{array}{l}\text { - IE01 (Create } \\
\text { Equipment) } \\
\text { - IE02 (Edit single) } \\
\text { - IE05 (Edit multiple) } \\
\text { ZSPPE_DATALOAD } \\
\text { (Upload) } \\
\text { - IE03 (Display) }\end{array}$ & $\begin{array}{l}\text { - Asset Data Maintainer } \\
\text { - Plant Maintenance } \\
\text { Master Data Maintainer } \\
\text { - RP Viewer }\end{array}$ & $\begin{array}{l}\text { Equipment records and } \\
\text { associated to functional } \\
\text { location }\end{array}$ \\
\hline \multicolumn{3}{|c|}{ Recommended Communication: } & \multicolumn{4}{|c|}{ Communicate completeness to appropriate maintenance entities } \\
\hline
\end{tabular}

Although documentation is available detailing the GFEBS functionality for uploading facility data, the pilot demonstrated the need for training, role assignment and accountability, and an installation-specific business process plan for facility data population in GFEBS. The ideas listed below highlight points to be considered for inclusion in the process. These points were developed based on observations and communications throughout the course of this project

Training on complete RP and IBE ${ }^{*}$ information life cycle. It is essential that key stakeholders understand the overall objectives, goals, and usability of the data requirements. During site visits it was evident that personnel clearly understood their own roles and responsibilities, but they were not aware of processes performed before or after their own actions, or how their role affects others.

Communication. Process effectiveness greatly relies on establishing continuous communication with appropriate personnel about upcoming construction project awards and a process for ensuring notification promptly upon award.

\section{Required participation in pre-construction and partnership} meetings. Identify required personnel and ensure that they attend the project's pre-construction and partnership meetings. Personnel attending the meetings should be aware of general RP and IBE information requirements. In particular, they should

\footnotetext{
* RP: real property. IBE: installed building equipment.
} 
- initiate or participate in meeting discussions about turnover RP and equipment information, to include delivery format, type of information to be collected, and equipment for which information will be collected

- provide all available RPUIDs to the project stakeholders

- at a minimum-and highly recommended-attend the project's partnership meeting in the later stages of the project (80\% completion).

Required information. Identify all available current information (e.g., RPUID, Functional Locations, IBE) for the project in all applicable information systems, including GFEBS, IFS, and other CAFM*CCMMS. Identifying this information early in the project is essential for preparing the system to receive the new information at turnover.

Individual responsibilities. Identify personnel responsible for all tasks in Table 3, specifically

- creation or modification of the RP record

- creation or modification of the Functional Locations record

- creation or modification of Equipment Information and/or equipment status.

Facility turnover. Communicate and execute turnover to maintenance personnel.

Records transmittal. Request and ensure receipt of preliminary record containing spaces and IBE information in agreed-upon format at substantial project completion point, before project reaches interim acceptance point.

Pre-acceptance meeting. Hold internal meeting before the interim acceptance point to follow up on

- accuracy and familiarization with Functional Locations, based on received list

- accuracy of equipment status (active/deactivated)

- communicate with personnel attending final inspection

- ensure receipt of project closeout documentation.

* CAFM: computer-aided facility management. 
Internal closeout. Hold internal closeout meeting after final acceptance of RP, and follow up on

- receipt of final RP and IBE information in agreed-upon format

- receipt of project closeout documentation

- verification of IBE

- process for continual update, if applicable.

Final turnover. Execute turnover to operations and maintenance personnel. 


\section{Summary and Recommendations}

\subsection{Summary}

This report documents several efforts and milestone accomplishments by a USACE Facility Data Exchange (FDE) working group established to identify Army facility data requirements, standardize data-exchange formats, and facilitate the collection, import, and export of data for use by downstream applications, with focus on those that populate the Army General Fund Enterprise Business System (GFEBS) with equipment inventory data. The group, consisting of members of the USACE/Industry BIM Consortium, developed a facility data guide specification (UFGS 017824.00 10) and a standardized data-delivery format (Facility Data Workbook, or FDW) to facilitate data collection and exchange with other applications that require the same data. The guide specification defines a prioritized set of systems, equipment, and components for which information will be required. It defines a set of attributes classified and structured around national standards. The FDW is a spreadsheet-based tool designed to assist in populating the required data and exporting it to other applications that need it. The FDW task focused on facilitating population of the Army's General Fund Enterprise Business System (GFEBS) with equipment inventory data.

Fort Benning, Fort Leonard Wood, and West Point participated in this project and selected a sample of their facilities for use in a pilot test of the FDW. A spreadsheet for each facility was developed and populated, and the GFEBS input process at each installation was tested and/or evaluated. Research performed before and during the pilot testing found that language requiring collection and delivery of facility and equipment data is already included in USACE and IMCOM construction contracts. This language is also found disseminated through many forms policy and specification documents. This pilot demonstration confirmed the need for coordinating the language of these specifications and development of cohesive policy and guidance that outlines which data are to be delivered and how the data should be delivered. 


\subsection{Recommendations}

The recommendations provided in this section begin with those directly related to the results and findings of this FDE pilot demonstration. The authors also offer suggestions, based on observations and lessons learned, that USACE, ACSIM, and IMCOM could consider to help expedite facility data exchange and integration for the benefit of all user and stakeholder organizations.

\subsubsection{FDE implementation recommendations}

1. Include the UFGS 0178.24 .0010 facility data exchange specification in all applicable projects.

2. Provide standard data formats for collection and submission of information needed in facility turnover. In specifying data formats, proponents should consider both the usefulness of the information and its transferability to O\&M applications.

3. Evaluate coordination of all specifications requiring facility data equipment handover. Examples of already required information can be found in UFGS 0178 oo (Sections 1.7, 3.6, and 3.9) and UFGS 017823 (Section 1.6).

4. Provide training on the objectives, goals, importance, and participation in the collection, exchange, and maintenance of RP and IBE information.

5. Establish procedures for early inclusion of installation personnel and/or representatives of the entity responsible for operation and maintenance of installed equipment; and discussion of installation needs as it relates to equipment operation and maintenance data at the pre-construction meeting/conference.

6. Evaluate potential for the standardized data format to be implemented as attachment to DD Form 1354.

\subsubsection{Related recommendations for USACE}

1. Consider issuing an Engineering and Construction Bulletin (ECB) mandating the use of the FDE specification (UFGS 0178 24.00 10).

2. Evaluate current USACE Learning Center PROSPECT ${ }^{*}$ courses for inclusion of FDE process training.

* PROSPECT: Proponent Sponsored Engineer Corps Training. 
3. Maintain continuous communication with installations to ensure that project requirements are included. Specifically, include a focus near completion of the project will improve the turnover process.

4. Improve quality control process and ensure enforcement of requirements related to facility data exchanges such as those highlighted in this report's Appendix ("Current Specifications and Policy," p 33).

5. Re-evaluate the definition and application of the term "asset," which is currently considered interchangeable with the term "equipment" as included in the text UFGS 017824.0010 and FDW. After evaluation of documentation related to collection and exchange of facility data, the PDT recommends adherence to established terminology as used in closeout and O\&M specifications. Misunderstanding and confusion about this terminology was also observed during interview and feedback meetings with collaborators during this project.

6. Investigate standardization of construction document schedules for major systems to improve interoperability and data-exchange potential.

\subsubsection{Related recommendations for ASCIM and IMCOM}

1. Develop or update policy or guidance to implement the FDE specification for internal acquisition projects.

2. Develop a detailed IBE requirement list. The pilot demonstration reinforced the need to have IMCOM and the installation clearly define the items to be included and submitted for the equipment-in-place list.

3. Evaluate current educational courses and resources available to DPW personnel and consider inclusion of FDE process training.

4. Maintain continuous communication with construction agents to ensure that O\&M requirements are included in projects. Ensure that the pre-construction meeting/conference and partnership meeting are convened as specified in UFGS 013000.

5. Consider ways to improve the quality-control process and ensure enforcement and delivery of operation and maintenance data requirements at project turnover.

6. If applicable, evaluate maintenance contractor's role/scope of work within the GFEBS CMMS data population and maintenance process. 


\section{References}

CAD-BIM Center. (n.d.). Retrieved from https://cadbimcenter.erdc.dren.mil

Department of Defense. (2004, October 13). DOD Directive 4165.06. Retrieved August 29, 2017, from Executive Services Directorate:

http://www.esd.whs.mil/Portals/54/Documents/DD/issuances/dodd/416506p. pdf

Department of Defense. (2009, April 16). UFC 1-30o-o8 Criteria for Transfer and Acceptance of DoD Real Property. Retrieved February 09, 2017, from Whole Building Design Guide: http://www.wbdg.org/ffc/dod/unified-facilities-criteriaufc/ufc-1-300-08

Department of Defense. (2014, January 17). DOD Insruction 4165.14. Retrieved March 20, 2017, from Executive Services Directorate: http://www.esd.whs.mil/Portals/54/Documents/DD/issuances/dodi/416514p.p df

Department of the Army. (2012, 01 23). General Fund Enterprise Business System. SAP Transaction and Command Codes Job Aid. Retrieved September 21, 2017, from https://www.us.army.mil/suite/doc/47815157

Department of the Army. (n.d.). GFEBS Role Descriptions Real Property. General Fund Enterprise Business System(Release 1.4). Retrieved o9 20, 2017, from https://www.us.army.mil/suite/doc/30739382

DITL 05 Create, Change and Deactivate Equipment Master. (2013, September 11). Retrieved from Army Knowledge Online: https://www.us.army.mil/suite/designer

EO 13327 Federal Real Property Asset Management. (2004, February 06). Retrieved August 15, 2017, from Whole Building Design Guide: http://www.wbdg.org/ffc/fed/executive-orders/eo-13327

Executive Services Directorate, DoD Directives Division. (n.d.). DoD Forms Management Program. Retrieved from Executive Services Directorate (ESD): http://www.esd.whs.mil/Portals/54/Documents/DD/forms/dd/dd1354.pdf

GSA. (2013, August 15). Federal Real Property Council. Retrieved August 29, 2017, from Guidance For Real Property Inventory Reporting:

https://www.gsa.gov/portal/getMediaData?mediaId=178911

Unified Facilities Guide Specifications. (2011, August 01). UFGS 0178 oo Closeout Submittals. (USACE, Ed.) Retrieved February 09, 2017, from Whole Building Design Guide: http://www.wbdg.org/ffc/dod/unified-facilities-guidespecifications-ufgs/ufgs-01-78-00

Unified Facilities Guide Specifications. (2015, August 01). UFGS o1 30 oo Administrative Requiremnts. (NAVFAC, Ed.) Retrieved August 18, 2017, from Whole Building Design Guide: http://www.wbdg.org/ffc/dod/unified-facilities-guidespecifications-ufgs/ufgs-01-30-00 
Unified Facilities Guide Specifications. (2015, August 08). UFGS 077823 Operation and Maintenance Data. (NAVFAC, Ed.) Retrieved August 18, 2017, from Whole Building Design Guide: http://www.wbdg.org/ffc/dod/unified-facilities-guidespecifications-ufgs/ufgs-01-78-23

Unified Facilities Guide Specifications. (2017, May 01). UFGS 0178 24.0O 10 Facility Data Requirements. (USACE, Ed.) Retrieved August 18, 2017, from Whole Building Design Guide: http://www.wbdg.org/ffc/dod/unified-facilities-guidespecifications-ufgs/ufgs-01-78-24-00-10 


\section{Appendix: Current Specifications and Policy}

\section{UFGS 0130 00, Administrative Requirements (2015)}

This specification outlines requirements for communication and coordination among the project participants. The PDT understands that the sections detailed below present potential for integration of key stakeholders and additional discussion related to data exchange.

Section 1.9 - Preconstruction Meeting/Conference. This section establishes the requirement for a coordination meeting between project award and site work commencement. The purpose of this meeting is to ensure stakeholder understanding of project requirements including administration and submittals. Discussion of requirements, format, and end goal for collection and exchange of facility data could be included as a topic in this meeting. Understanding of the product, systems, and equipment for which information is needed and the format to be used is a critical step in achieving smooth data turnover. Failure of early discussion will likely result in incorrect or not useful data requiring re-collection and re-entry by the end user.

Section 1.10 - Facility Turnover Planning Meeting. This paragraph covers contractor and government meeting to strategize for efficient closure and turnover. Although this section is tailored for Navy projects, it seems appropriate and crucial for all projects to start the turnover process during the preconstruction meeting/conference as suggested in this section.

Section 1.13 - Partnering. This section requires the establishment of partnerships among the key stakeholders in the project including the government, contractor, subcontractors, and end user, among others. The objective is a smoother and more efficient accomplishment of the project within budget and schedule. This section establishes that this partnership may be formal (section 1.13.1) or informal (section 1.13.2) depending on the complexity and risk associated with the project.

Findings of this project suggest that the contracting officer, who is responsible for organization of the partnership, should ensure the involvement of 
the installation and key maintenance personnel. At a minimum, these individuals should participate in the initial partnering session, to be scheduled for the pre-construction meeting/conference, and any session after considerable percentage of project completion $(60 \%-80 \%)$.

Early involvement of the end user was a recurring issue raised throughout the pilot project, and the partnership appears to be an established forum for accomplishing this. The PDT understands such involvement is a shared responsibility, and that the installation should be as diligent as the contracting officer in the involvement.

\section{UFGS 0178 00, Closeout Submittals (2011)}

This specification outlines requirements for submission of the closeout documents. These include warranty and manufacturer procedures to ensure appropriate operation and maintenance of the installed equipment. Language in this specification incorporates options for NASA* and Armyspecific processes. The PDT observed inconsistencies and room for improvement in the implementation and/or quality-control processes covered by the sections below.

Section 1.7.1 - Warranty Management Plan. This section requires submission of warranty management plans at least 30 days before the prewarranty conference. The section also establishes that warranty information is to be submitted and accepted by the contracting officer prior to monthly payment estimate. Furthermore, it requires a joint warranty inspection to be conducted 4 and 9 months from acceptance. The inspection should be attended by the contractor, contracting officer, and customer representatives. The following items are to be included in the management plan:

- Status and certificates for a defined list of systems including HVAC, Fire Protection, Pumps, and Transforms

- A list of defined attributes to be submitted for each warranty equipment, item, feature or system

It was found that the requirements for equipment, items, and systems to be listed, as well as the list of defined properties in the specification, have

\footnotetext{
* NASA: National Aeronautics and Space Administration.
} 
significant similarities to requirements in the FDW. This UFGS section, however, does not define a format to deliver this information. The PDT found this to be a gap in the process. Definition of a delivery format will improve consistency in the process and will ensure that the information can be useful to the end customer.

Section 1.7.3 - Pre-Warranty Conference. This section establishes the requirement to hold a meeting before project completion to discuss and agree on warranty requirements. The PDT understands the pre-warranty meeting is an opportunity to discuss and follow up on the format for submittal of warranty information. It also helps to ensure that information about all needed products, equipment, and systems is being included.

Section 1.7.4 - Contractor's Response to Construction Warranty Service Requirements. This section establishes the requirement for warranty service in accordance to a priority list. Priority codes (1, 2 and 3) included as requirements in the FDW are defined in this section. A list of priority codes for specific systems is also included within the section. Although a requirement, the PDT found this attribute was not required on any of the other formats observed in the pilot project.

Section 1.7.5 - Warranty Tags. This section requires a tag at installation time for each item of warrantied equipment, shown in Figure A1, with a defined set of properties.

The PDT observed inconsistency in the enforcement of equipment tags. Tags were available in 1 of the 4 buildings inspected by the PDT. The other three buildings were missing either some or all equipment tags.

The PDT considers enforcement of this requirement to be essential for quality control of submitted information. Tags also provide easy and fast access to nameplate equipment information for maintenance personnel. 
Figure A1. Warranty tag property requirements.

\begin{tabular}{|c|c|}
\hline Type of product/material & \\
\hline Mode1 number & \\
\hline Serial number & \\
\hline Contract number & \\
\hline Warranty period from/to & \\
\hline Inepector's signature & \\
\hline Conatruetion Contractor & \\
\hline Address & \\
\hline Telephone number & \\
\hline Warranty contact & \\
\hline Addresa & \\
\hline Telephone number & \\
\hline $\begin{array}{l}\text { Karranty reaponae time } \\
\text { priority code }\end{array}$ & \\
\hline $\begin{array}{l}\text { KARQING - PRONECT PERSOSE } \\
\text { KARRANTY PERIOD. }\end{array}$ & PERPORM ONLY ODERATIOEAL MAINTENAMCE DURING THE \\
\hline
\end{tabular}

Section 2.1 - Government Furnished Materials. This section details materials to be provided by the government. The PDT found that templates of specific formats for data collection and exchange such as the FDW can be included as government furnished materials.

Section 3.6 - As-Built Record of Equipment and Materials. This section establishes the requirement for submittal of preliminary record of equipment and materials before final inspection. This record comes in the form of a list and shall include the properties shown in Figure A2. The specification also establishes government responsibility for revision and commenting on the provided list.

A specific format for submission of the Record of Designated Equipment and Materials Data is not established, but this project shows that adding such requirement can aid in review and turnover processes. 
Figure A2. Data required on Record of Designated Equipment and Materials.

\begin{tabular}{|l|l|l|l|l|}
\hline \multicolumn{5}{|c|}{ RECORD OF DESIGNATED EQUI PMENT AND MATERIALS DATA } \\
\hline Description & $\begin{array}{l}\text { Specification } \\
\text { Section }\end{array}$ & $\begin{array}{l}\text { Manufacturer } \\
\text { and Catalog, } \\
\text { Mode1, and } \\
\text { Serial Number }\end{array}$ & $\begin{array}{l}\text { Composition and } \\
\text { size }\end{array}$ & Where Used \\
\hline & & & & \\
\hline & & & & \\
\hline
\end{tabular}

Section 3.9 - Real Property Record. This section establishes the requirement to submit a DD Form 1354 (DoD Forms Management Program) for all DoD projects. It establishes that the final copy of the form will be submitted to the applicable entity for entering of information into the real property database. The guide specification establishes that the draft form shall be updated and submitted at least 60 days before final acceptance of work.

The PDT understands there is an opportunity for coordination and communication with the end customer upon submission of this record. Furthermore, the PDT suggests that updated version of specific format selected for exchange of facility data, such as the FDW, could be required as an attachment to this submittal.

\section{UFGS 0178 23, Operation and Maintenance Data (2015)}

This specification outlines the requirements for Operation and Maintenance submittal packages. The specification includes tailoring options for specific Army and Naval Facilities Engineering Command (NAVFAC) processes. Army-specific process refers to the Facility Data Requirements (UFGS 0178 24.00 10).

Section 1.3 - Operation and Maintenance Data. This section establishes the requirement for submitting O\&M data. It requires data to be structured in an organized manner that clearly defines the importance of system interaction. Organizational structure should also provide clear understanding of the O\&M requirements at all levels.

The Army-specific requirement for the Facility Data Set (FDS) in UFGS 01 7824.0010 is intended to clarify and provide further detail and structure to the information required in this section. 
Section 1.6.4 - Real Property Equipment. This section establishes the requirement for submittal of the "Equipment-In-Place List" that should contain nameplate information for each installed piece of equipment. The final list should be available soon after transfer of the facility, and must include these required properties:

- Description

- Location by room number

- Model Number

- Serial Number

- Capacity

- Manufacturer

- Equipment supplier

- Condition

- Spare parts list

- Manufacturer's catalog

- Warranty

A specific format for the Equipment-In-Place List is not established, but the results of this pilot project show that adding such a requirement can assist in review and transfer of information.

\section{UFGS 017824.00 10, Facility Data Requirements (2017)}

This specification, developed specifically for Army projects, details requirements for electronic collection, organization, and exchange of facility data. It establishes, defines, and requires the use of the Facility Data Workbook (FDW) as a format for data collection and the Facility Data Set (FDS) for organization of O\&M documentation.

The PDT found that there is need for improvement in the establishment of required assets for which information should be collected and transferred. It was found that due to requirements variations among projects, the specification and tools shall clearly define a process for tailoring. It was also found that requirements are highly influenced by their importance to end customer and, as such, coordination with this entity should begin early in the project. Lastly it was found that this specification presents a deficiency in the utilization of the term "asset" as interchangeable for the term "equipment." This point is included and further discussed in section 4.2.2 of the main report. 


\section{UFC 1-300-08, Instructions on Completing DD Form 1354 (DoD 2009)}

This document details the process for completing the required DD Form 1354. As stated before, this form is required on all DoD projects for accurate accountability and tracking of real property assets. The following are key factors included in the document:

- Type of acquisitions covered by the UFC

- Types of DD 1354 and their definitions and requirements based on the acquisition type

- Roles and responsibilities in the development and dissemination of information included in the form; listed participants in the transfer and acceptance process include the

○ Construction Agent

- Sponsoring Entity

- Real Property Accountable Officer (RPAO) or Accepting Official Realty Staff

- Directorate of Public Works/Facilities Management Office/Base Civil Engineer (DPW/FMO/BCE)

Information on DD Form 1354 can often originate from or be found in DD Form 1391 for military construction (MILCON) projects.

It is specified that the final form is usually accompanied with supporting documentation that represents a potential area for integration of specific formatted facility data requirements.

Compliance with development and submission of this requirement was found to be the most consistent item within the pilot-study facilities.

\section{Executive Order 13327, Federal Property Asset Management}

This 2004 Executive Order is the basis of all Federal real property mandates, policies and procedures. The order establishes the Federal Real Property Council (FRPC) to develop guidance and serve as a facilitator for agencies to achieve the goals established in their agency's asset-management plans. Furthermore, this order requires the designation of a Senior Real Property Officer in each agency responsible for the development, implementation, and submittal of an asset-management planning process that follows FRPC requirements. The intent behind this Executive Order is to promote the efficient use of and accountability for Federal government 
real property. It was also intended that establishment of such procedures will assist the decision-making process in terms of Federal real property funding and reforms.

\section{DoD Instruction 4165.14, Real Property Inventory (RPI) (2014)}

This instruction outlines the requirements and procedures for DoD components to report collected Real Property Inventory (RPI) data to the DoD level. The Applicability section in this instruction excludes Real Property Install Equipment (RPIE), Installed Building Equipment (IBE), and any other item categorized as non-real property asset from this reporting requirement. 


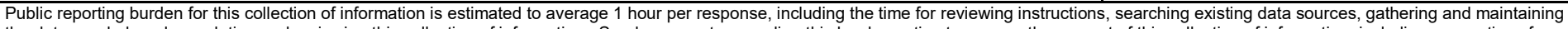

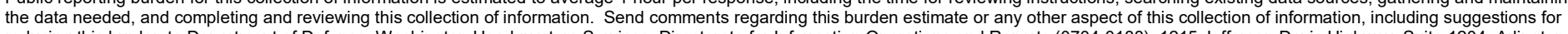

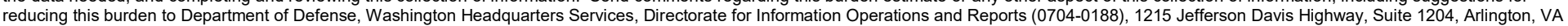

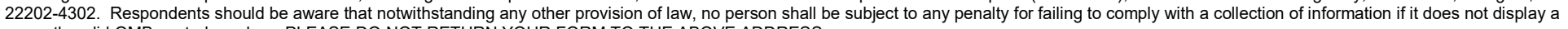
currently valid OMB control number. PLEASE DO NOT RETURN YOUR FORM TO THE ABOVE ADDRESS.
1. REPORT DATE (DD-MM-YYYY)
September 2018
2. REPORT TYPE
Final
3. DATES COVERED (From - To)

\section{TITLE AND SUBTITLE}

Facility Data Exchange Pilot Demonstration for the Army General Fund Enterprise Business System (GFEBS)

5a. CONTRACT NUMBER

\section{5b. GRANT NUMBER}

5c. PROGRAM ELEMENT NUMBER ITTP

6. AUTHOR(S)

Beth A. Brucker, Mariangelica Carrasquillo-Mangual, Andy C. Temeyer, Jillian M. Martin, and Carl S. Mudd

5d. PROJECT NUMBER

Project P2 457492

5e. TASK NUMBER

Customer Order 10930002

5f. WORK UNIT NUMBER

7. PERFORMING ORGANIZATION NAME(S) AND ADDRESS(ES)

U.S. Army Engineer Research and Development Center (ERDC)

Construction Engineering Research Laboratory (CERL)

8. PERFORMING ORGANIZATION REPORT NUMBER

ERDC/CERL TR-18-26

PO Box 9005

Champaign, IL 61826-9005

\section{SPONSORING / MONITORING AGENCY NAME(S) AND ADDRESS(ES)}

Office of the Assistant Chief of Staff for Installation Management (OACSIM)

Facilities Branch (DAIM-ODF)

600 Army Pentagon

Washington, D.C. 20310

10. SPONSOR/MONITOR'S ACRONYM(S)

OACSIM

11. SPONSOR/MONITOR'S REPORT NUMBER(S)

\section{DISTRIBUTION / AVAILABILITY STATEMENT}

Approved for public release. Distribution is unlimited.

\section{SUPPLEMENTARY NOTES}

\section{ABSTRACT}

The USACE/Industry BIM Consortium has been developing a specification and standardized delivery process for collecting and exchanging facility data required by the Department of Defense and the Army for downstream applications. This effort produced a new Unified Facilities Guide Specification, UFGS 017824.0010 (Facility Data Requirements), which defines a prioritized set of assets and data attributes. A project-development team performed a pilot study to validate that these assets and attributes meet the Army's needs for populating their Operations and Maintenance data systems.

The focus of the pilot study was to verify that asset data collected during facility construction at three Army installations could effectively be imported to the Army General Fund Enterprise Business System (GFEBS). With the help of GFEBS experts from Installation Management Command, the project team developed a Facility Data Workbook (FDW), a spreadsheet application that facilitates the collection of facility data and translates the data into the GFEBS equipment input format. An FDW was developed for each selected facility at the pilot sites and the GFEBS input process at each installation was evaluated. Recommended changes to the specification have been drafted and will be evaluated for inclusion in an update to the guide specification.

\section{SUBJECT TERMS}

Military bases-Buildings-Information storage and retrieval systems; Building information modeling; Military construction operations; Data curation

\begin{tabular}{|c|c|c|c|c|c|}
\hline 16. SECURITY CL & IFICATION OF: & & $\begin{array}{l}\text { 17. LIMITATION } \\
\text { OF ABSTRACT }\end{array}$ & $\begin{array}{l}\text { 18. NUMBER } \\
\text { OF PAGES }\end{array}$ & $\begin{array}{l}\text { 19a. NAME OF RESPONSIBLE } \\
\text { PERSON }\end{array}$ \\
\hline $\begin{array}{l}\text { a. REPORT } \\
\text { Unclassified }\end{array}$ & $\begin{array}{l}\text { b. ABSTRACT } \\
\text { Unclassified }\end{array}$ & $\begin{array}{l}\text { c. THIS PAGE } \\
\text { Unclassified }\end{array}$ & UU & 49 & $\begin{array}{l}\text { 19b. TELEPHONE NUMBER } \\
\text { (include area code) }\end{array}$ \\
\hline
\end{tabular}

